\title{
KONTRIBUSI KECERDASAN NATURALIS DAN SIKAP PEDULI SOSIAL TERHADAP KOMPETENSI PENGETAHUAN IPS SISWA KELAS IV SD
}

\author{
I M. Manuh Pramana1 ${ }^{1}$ I W. Sujana², I K. Ngurah Wiyasa ${ }^{3}$ \\ ${ }^{1} J u r u s a n$ Pendidikan Dasar, Universitas Pendidikan Ganesha, Singaraja, Indonesia \\ 2Jurusan Pendidikan Dasar, Universitas Pendidikan Ganesha, Singaraja, Indonesia \\ ${ }^{3}$ Jurusan Pendidikan Dasar, Universitas Pendidikan Ganesha, Singaraja, Indonesia \\ e-mail: \{made.manuh.pramana, iwayan.sujana,ngrh.wiyasa\}@undiksha.ac.id
}

\begin{abstract}
Abstrak
Penelitian ini bertujuan untuk mengetahui kontribusi yang signifikan kecerdasan naturalis dan sikap peduli sosial terhadap kompetensi pengetahuan IPS siswa kelas IV SD Negeri Gugus III Mengwi Tahun Pelajaran 2018/2019. Penelitian ini menggunakan rancangan "ex post facto" dengan jenis studi korelasi. Populasi yang digunakan dalam penelitian ini adalah siswa kelas IV SD Gugus III Mengwi Tahun Ajaran 2018/2019. Dengan jumlah populasi 264 siswa. Dalam penelitian ini sampel ditentukan menggunkaan Teknik Proposional Random Sampling, dan mendapatkan sampel sebanyak 150 siswa. Metode pengumpulan data dalam penelitian ini meliputi data tentang kecerdasan naturalis, sikap peduli sosial dan kompetensi pengetahuan IPS dengan menggunakan metode non test, dalam pengumpulan data pada variable bebas menggunakan angket sedangkan dalam variabel terikat menggunakan teknik pencatatan dokumen. Uji prasyarat analisis dalam penelitian ini menggunakan, uji normalitas Kolmogorov-Smirnov, uji linieritas, uji multikolinieritas dan uji heteroskedastisitas. Setelah seluruh uji prasyarat terpenuhi, maka dilanjutkan menguji hipotesis dengan menggunakan teknik analisis regresi linier ganda. Hasil yang didapat yaitu nilai $F_{\text {hitung }}=3,68>F_{\text {tabel }}$ $=3,06$ berarti signifikan antara kecerdasan naturalis dan sikap peduli sosial terhadap kompetensi pengetahuan IPS dan kontribusinya sebesar 4,8\%. Hal ini memperlihatkan bahwa 95,2\% dipengaruhi oleh faktor lain, seperti lingkungan belajar, hubungan sosial, intelegensi, minat, bakat, rasa ingin tahu. Dapat disimpulkan bahwa terdapat pengaruh yang signifikan kecerdasan naturalis dan sikap peduli sosial terhadap kompetensi pengetahuan IPS. Pada penelitian ini mampu meningkatkan rasa sikap peduli sosial dan mampu menumbuhkan kecerdasan naturalis, ditujukan agar guru dapat meningkatkan kecerdasan naturalis dan sikap peduli sosial siswa sehingga tercapai kompetensi pengetahuan IPS yang baik
\end{abstract}

\author{
Keywords: \\ Kecerdasan naturalis, \\ sikap peduli sosial
}

\section{Pendahuluan}

Pendidikan dasar merupakan hal yang sangat penting sebagai pondasi kehidupan seseorang. Pendidikan tingkat dasar dipandang sebagai tahap dasar dalam proses berkelanjutan pendidikan seumur hidup dan dianggap sangat penting bagi semua orang sebagai landasan pendidikan lebih lanjut sepanjang hidup Ranaweera, (Anna 2016:2). Permendikbud Nomor 103 Tahun 2014 tentang Pembelajaran pada Pendidikan Dasar dan Pendidikan Menengah, menyatakan bahwa "Tujuan proses pembelajaran memberikan kesempatan kepada peserta didik untuk mengembangkan potensi mereka menjadi kemampuan yang semakin lama semakin meningkat dalam sikap spiritual dan sosial, pengetahuan dan keterampilan yang diperlukan dirinya untuk hidup dan untuk bermasyarakat, berbangsa, serta berkontribusi pada kesejahteraan umat manusia". 
Dalam pendidikan ini berlangsung suatu proses antara guru dengan peserta didik untuk mencapai sebuah tujuan pembelajaran. Berkaitan dengan hal tersebut, dirancanglah sebuah pedoman dalam kegiatan pembelajaran yang disebut dengan kurikulum. Kurikulum terbaru yang digunakan dalam pendidikan di Indonesia adalah Kurikulum 2013. Pandangan ini menjadikan Kurikulum 2013 dikembangkan berdasarkan budaya bangsa Indonesia yang beragam, diarahkan untuk membangun kehidupan masa kini dan untuk membangun dasar bagi kehidupan yang lebih baik di masa depan.

Kurikulum 2013 menganut pandangan dasar bahwa pengetahuan tidak dapat dipindahkan begitu saja dari guru ke peserta didik. Namun, peserta didik adalah subjek yang memiliki kemampuan untuk secara aktif mencari, mengolah, mengkonstruksi dan menggunakan pengetahuannya sebagai proses berlangsungnya pembelajaran. Menurut Permendikbud nomor 22 tahun 2016 pada bagian proses pembelajaran menyatakan "Proses pembelajaran pada satuan pendidikan diselenggarakan secara interaktif, inspiratif, menyenangkan, menantang, memotivasi peserta didik untuk berpartisipasi aktif, serta memberikan ruang yang cukup bagi prakarsa, kreativitas, dan kemandirian sesuai dengan bakat, minat, dan perkembangan fisik serta psikologis peserta didik". Untuk itu setiap satuan pendidikan melakukan perencanaan pembelajaran, pelaksanaan proses pembelajaran serta penilaian proses pembelajaran untuk meningkatkan efisiensi ketercapaian kompetensi lulusan, khususnya dalam kompetensi pengetahuan IPS. Kompetensi pengetahuan dapat dengan jelas mengukur kemampuan siswa dalam memahami dan menguasai isi dari suatu materi atau bahan pelajaran. Kompetensi pengetahuan juga dapat dinyatakan sebagai kompetensi pada ranah kognitif yang mampu mengukur tingkat penguasaan atau pencapaian siswa dalam aspek pengetahuan yang meliputi ingatan atau hafalan, pemahaman, penerapan atau aplikasi, analisis, sintesis dan evaluasi (Kunandar, 2014:168).

Ilmu Pengetahuan Sosial atau yang sering di singkat dengan IPS adalah suatu ilmu pengetahuan yang yang lebih banyak mengkaji tentang kehidupan sosial (Gunawan 2013:17). Di sekolah dasar kompetensi pengetahuan IPS membahas tentang hubungan antara manusia dengan lingkungannya. Lingkungan masyarakat siswa tumbuh dan berkembang sebagai bagian dari masyarakat, dihadapkan pada berbagai permasalahan yang ada dan terjadi di lingkungan sekitarnya. Pendidikan IPS berusaha membantu siswa dalam memecahkan permasalahan yang dihadapi sehingga dapat menjadikannya semakin mengerti dan memahami lingkungan sosial masyarakat.

Namun adanya kesenjangan sekolah dengan harapan masyarakat yang diciptakan oleh siswa ini bermuara pada kesenangan terhadap pembelajaran IPS. Kenyataannya pembelajaran IPS terkesan membosankan bagi siswa karena muatan pembelajaran IPS kebanyakan membahas dan mengupas dalam mengenai aspek sejarah serta yang berhubungan tentang masalah sosial yang terjadi di masyarakat. Hal itu disebabkan guru kebanyakan hanya mengisi jam pelajaran dan membelajarkan siswa tanpa memahami kecerdasan naturalis dan tanpa adanya saling interaksi yang positif antar peserta didiknya. Hal tersebut didukung dengan fakta pada saat pengamatan yang dilakukan oleh peneliti, pembelajaran IPS yang berlangsung di kelas IV. Tidak terdapat aktivitas berarti yang ditunjukkan dari siswa pada saat proses pembelajaran berlangsung. Selain itu, beberapa siswa kurang mampu mempergunakan lingkungan disekitarnya dengan baik untuk dipakai menjadi sumber belajar.

Rendahnya kompetensi pengetahuan IPS yang dicapai peserta didik tidak terlepas dari faktor-faktor yang memengaruhi kompetensi pengetahuan tersebut. Faktor yang memengaruhi kompetensi pengetahuan dikelompokan menjadi dua bagian yaitu faktor internal dan faktor eksternal. Faktor internal yang memengaruhi kompetensi pengetahuan adalah kondisi fisik, seperti kesehatan organ tubuh, kondisi psikis seperti kemampuan intelektual, emosional, dan kondisi sosial, seperti kemampuan bersosialisasi dengan 
lingkungannya. Sedangkan faktor eksternal yang memengaruhi kompetensi pengetahuan yaitu adanya variasi dan tingkat kesulitan materi belajar yang dipelajari, tempat belajar, iklim, suasana lingkungan belajar.

Kegiatan untuk memelihara kondisi lingkungan yang mampu mendukung kehidupan merupakan kewajiban semua individu, termasuk peserta didik. Peserta didik diharapkan memiliki pengetahuan, kepedulian, dan keterampilan serta sikap yang positif terhadap lingkungan. Tindakan yang berupaya untuk mencegah dan memperbaiki kerusakan pada linngkungan alam yang terjadi, serta melestarikannya merupakan salah satu ciri seseorang yang memiliki kecerdasan naturalis.

Kecerdasan naturalis merupakan jenis kecerdasan yang ada dalam teori Multiple Intelligences. Gardner (2013:33) menyatakan "orang yang memiliki tingkat kecerdasan naturalis yang tinggi sangat sadar akan bagaimana membedakan tanaman, hewan, pegunungan, atau konfigurasi awan yang berbeda dalam ceruk ekologis mereka". Lebih lanjut, dalam Amstrong (2013:212) menjelaskan bahwa "dalam dunia nyata naturalis muncul sebagai orang yang memiliki kemahiran dalam berkebun, memelihara tanaman di dalam rumah, menggarap taman yang indah, atau memperlihatkan suatu perhatian alami terhadap tanaman dengan cara-cara lain". Begitu pula dengan seseorang yang mempunyai keluwesan dalam menghadapi makhluk hidup lainnya. Kecerdasan naturalis ini merupakan kecerdasan melibatkan kemampuan untuk mengenali bentuk-bentuk alam sekitar atau lingkungan. Anak-anak kecil dapat dengan mudah melakukan pembedaan dalam dunia naturalis (Gardner, 2013: 33). Menurut Amstrong (2013: 80), "Anak-anak yang condong sebagai naturalis akan menjadi bersemangat ketika terlibat dalam pengalaman di alam terbuka". Kecerdasan naturalis merupakan kecerdasan yang penting untuk dimiliki di zaman sekarang ini. Hal tersebut dikarenakan saat ini alam di seluruh dunia mendapat serangan dari kekuatan pembangunan, teknologi dan ekonomi, sehingga sangat membutuhkan orang-orang naturalis untuk merawat dan memperdulikan lingkungan, mulai dari lingkungan sekolah peserta didik sejak dini harus diajarkan perduli terhadap lingkungan sekitar yang akan membentuk karakter mereka. Dalam kamus psikologi, karakter adalah kepribadian yang ditinjau dari titik tolak etis atau moral, misalnya kejujuran seseorang yang biasanya mempunyai kaitan dengan sifat-sifat yang relatif tetap. Pendidikan karakter berupaya menanamkan nilai-nilai sosial dalam peserta didik. Nilai-nilai sosial perlu ditanamkan kepada peserta didik karena akan berfungsi sebagai kerangka acuan dalam berinteraksi dan berperilaku dengan sesama sehingga keberadaannya dapat diterima di masyarakat, (Zubaedi, 2011:39).

Setiap anak adalah keunikan dan mereka memiliki ciri khas, minat, serta bakat masing-masing. Jika boleh dikatakan, saat seseorang anak tak mengalami kelemahan fisik dan psikis maka biasa dipastikan anak tersebut dikatakan anak yang berbakat. Berbakat dibidang tertentu dan mungkin tidak berbakat dibidang lainnya. Masing-masing memiliki karakteristik sendiri, baik anak-anak yang tumbuh dengan normal maupu berkebutuhan khusus. Jika selama ini kita hanya mengetahui kecerdasan intelektual saja (IQ) maka hal tersebut hanya salah satu jenis kecerdasan yang dimiliki oleh seorang anak. Kecerdasan naturalis merupakan salah satu dari delapan macam kecerdasan yang telah ditemukan sampai saat ini Menurut Armstrong (20013: 7) Dimana kecerdasan naturalis adalah keahlian dalam mengenali dan mengklasifikasikan berbagai spesies flora dan fauna. Kecerdasan naturalis menurut Gardner (2013: 17) adalah kemampuan untuk mengenali, membedakan, mengungkapkan dan membuat kategori terhadap apa yang di jumpai di alam maupun lingkungan. Intinya adalah kemampuan manusia untuk mengenali tanaman, hewan dan bagian lain dari alam semesta. Kecerdasan naturalis adalah kemampuan dalam melakukan kategorisasi dan membuat hierarki terhadap keadaan organisme seperti tumbuh-tumbuhan, binatang dan alam Armstrong (2013:10). Budiningsih (2005) mendefinisikan bahwa kecerdasan naturalis adalah kecerdasan yang berkaitan dengan kemampuan individu mengenali, memahami, dan mengenali tanda-tanda pada lingkungan alam atau perubahan alam dengan melihat tanda-tandanya. Bahkan kemampuan melihat segi-segi keindahan dan keteraturan sehingga jenis kecerdasan ini lebih banyak dimiliki orang-orang pakar lingkungan atau yang peduli terhadap lingkungan.

Kecerdasan naturalis ialah kemampuan untuk mengenali, membedakan, menggolongkan, dan membuat kategori terhadap apa yang dijumpai di alam maupun di lingkungan. Salah satu metode dalam penerapan kecerdasan ini adalah metode kunjungan lapangan. (Sholeh dkk, 2016:30) metode kunjungan lapangan atau karyawisata adalah cara mengajar yang dilaksanakan dengan mengajak 
siswa ke suatu tempat atau objek tertentu di luar sekolah untuk mempelajari atau menyelidiki suatu peternakan, perkebunan, dan lingkungan. Anak-anak dengan kecerdasan naturalis yang menonjol memiliki ketertarikan yang besar terhadap alam sekitar, termasuk pada binatang, di usia yang sangat dini. Mereka menikmati benda-benda dan cerita yang berkaitan dengan fenomena alam, misalnya terjadinya awan dan hujan, asal usul binatang, pertumbuhan tanaman, dan tata surya.

Berdasarkan beberapa definisi di atas bahwa kecerdasan naturalis pada intinya berkaitan dengan isi alam, yaitu baik flora maupun fauna. Oleh sebab itu dapat kita sintesiskan bahwa kecerdasan naturalis adalah kemampuan mengenali, membedakan, mengungkapkan dan membuat kategorisasi yang berhubungan, dengan flora (tumbuhan) dan fauna (binatang) serta benda-benda alam yang ada di lingkungan sekitar. Manusia pada dasarnya adalah makhluk sosial, memiliki naluri untuk hidup dengan orang lain. Manusia mempunyai naluri untuk senantiasa berhubungan dengan sesamanya. Hubungan yang sinambung tersebut menghasilkan pola pergaulan yang dinamakan pola interaksi sosial. Kelompok sosial atau social group adalah himpunan atau kesatuan manusia yang hidup bersama, karena adanya hubungan di antara mereka. Hubungan tersebut antara lain menyangkut hubungan timbal balik yang saling memengaruhi dan juga suatu kesadaran untuk saling menolong, sikap peduli sosial terhadap sesama, Soekanto (2012) Peduli sosial adalah sikap dan tindakan yang selalu ingin memberi bantuan bagi orang lain dan masyarakat yang membutuhkan. Individu maupun kelompok melakukan interaksi untuk memenuhi kebutuhannya, seperti ingin memberikan bantuan bagi orang lain, saling membutuhkan satu sama lainnya dan gotong royong.

Makhluk sosial berarti bahwa hidup menyendiri tetapi sebagian besar hidupnya saling ketergantungan, yang pada akhirnya tercapai keseimbangan relatif. Maka dari itu, seharusnya manusia memiliki kepedulian sosial terhadap sesama agar tercipta keseimbangan dalam kehidupan. Bentukbentuk kepedulian sosial dapat dibedakan berdasarkan lingkungan. Lingkungan yang dimaksud merupakan lingkungan dimana seseorang hidup dan berinteraksi dengan orang lain yang biasa disebut lingkungan sosial. La Pierre dalam Azwar (2003) mengidentifikasikan peduli sosial sebagai suatu pola perilaku, tendensi atau kesiapan antisipatif, predisposisi untuk menyesuaikan diri dalam situasi sosial. Peduli sosial terbentuk dari adanya interaksi sosial yang dialami oleh individu. Interaksi sosial mengandung arti lebih dari pada sekedar adanya kontak sosial dan hubungan antar individu sebagai anggota kelompok sosial. Dalam interaksi sosial, terjadi hubungan saling memengaruhi diantara individu yang satu dengan yang lain, terjadi hubungan timbal balik yang turut memengaruhi pola perilaku masing-masing individu sebagai anggota masyarakat. Kepedulian sosial adalah sebuah tindakan, bukan hanya sebatas pemikiran atau perasaan. Tindakan peduli sosial tidak hanya tahu sesuatu yang yang salah dan benar, tapi ada kemauan melakukan gerakan membantu orang lain. Dengan memiliki jiwa sosial yang tinggi, anak didik lebih mudah bersosialisasi serta lebih dihargai. Pembentukan jiwa sosial anak didik dapat dilakukan dengan mengajarkan dan menanamkan nilai-nilai kepedulian sosial melalui kegiatan yang bersifat sosial, melakukan aksi sosial, dan menyediakan fasilitas untuk menyumbang (Kurniawan, 2013: 157-158). Berdasarkan penjelasan tersebut dapat dirangkum bahwa sikap peduli sosial adalah rasa perihatin atau kasihan yang dimiliki oleh manusia untuk melakukan sikap dan tindakan yang selalu ingin memberi bantuan kepada orang lain dan masyarakat yang membutuhkan.

Sebuah interaksi dilakukan ketika masing-masing individunya memiliki sikap peduli sosial untuk saling mengerti satu sama lain dengan apa yang mereka komunikasikan, saling membantu jika ada orang lain atau masyarakat yang kesusahan, sehingga dari pengertian tersebut menjelaskan bahwa sikap peduli sosial sangatlah dibutuhkan dalam melakukan interaksi terhadap orang lain. Agar kita dapat mengerti dan memahami apa yang dirasakan dan dilihat seseorang dan dapat membantunya dengan hati yang tulus ikhlas sesuai dengan apa yang orang lain dan masyarakat butuhkan. Dengan demikian sikap peduli sosial memiliki hubungan yang erat dengan interaksi sosial. Tumbuhnya sikap peduli sosial karena adanya interaksi terhadap orang lain. Sikap peduli sosial sangat berpengaruh terhadap kompetensi pengetahuan siswa, terutama untuk mengembangkan potensinya dalam pembelajaran IPS. Pada intinya pendidikan IPS diarahkan pada proses pengembangan peserta didik agar peka terhadap masalah sosial yang terjadi di masyarakat, memiliki sikap mental positif terhadap 
perbaikan segala ketimpangan yang terjadi, dan terampil mengatasi setiap masalah yang terjadi sehari-hari, baik yang menimpa dirinya sendiri maupun yang menimpa masyarakat.

Dalam penelitian ini terdapat dua variabel bebas dan satu variabel terikat, variabel bebeas yaitu kecerdasan naturalis $\left(\mathrm{X}_{1}\right)$, sikap peduli sosial $\left(\mathrm{X}_{2}\right)$ dan variabel terikat yaitu kompetensi pengetahuan IPS (Y). Kecerdasan naturalis memiliki indikator diantaranya, (1) Memperlihatkan ketertarikan terhadap tumbuhan dan binatang, (2) Senang merawat hewan maupun tumbuhan, (3) Suka berkegiatan di alam terbuka, (4) Memiliki ketertarikan yang tinggi dan pemahaman yang baik dalam topik-topik atau proyek-proyek yang berbasis alam, (5) Menunjukkan kepekaan terhadap bentukbentuk alam, (6) Mengenal dan membedakan berbagai jenis bebatuan, flora, suka berada di kebun, taman, akuarium, atau sistem kehidupan lain dan fauna, (7) Suka berada di kebun, taman, akuarium, atau sistem kehidupan lain, (8) Yakin bahwa binatang mempunyai hak sendiri, (9) Mempunyai catatan fenomena hewan, tanaman, dan hal-hal sejenis. Sikap peduli sosial memiliki indikator diantaranya, (1) Tolong menolong, (2) Empati, (3) Kerja sama, (4) Disiplin, (5) Toleransi, (6) Peduli.

Penelitian ini bertujuan untuk mengetahui pengaruh yang signifikan kecerdasan naturalis terhadap kompetensi pengetahuan IPS siswa kelas IV SD Gugus III Mengwi. Untuk mengetahui sikap peduli sosai terhadap kompetensi pengetahuan IPS siswa kelas IV SD Gugus III Mengwi. Serta untuk mengetahui pengaruh yang signifikan kecerdasan naturalis dan sikap peduli sosisal terhadap kompetensi pengetahuan IPS siswa kelas IV SD Gugus III Mengwi.

\section{Metode}

Penelitian ini dilakukan pada Siswa Kelas IV SD Negeri Gugus III Mengwi Tahun Pelajaran $2018 / 2019$, dengan tidak memanipulasi variabel bebas atau menggali fakta yang sudah terjadi sebelumnya sehingga penelitian ini tergolong penelitian ex post facto. Dantes (2012:61) menyatakan, Penelitian ex post facto adalah penelitian dengan mengambil kelompok-kelompok yang berbeda dan peneliti berusaha menentukan perbedaan-perbedaan ini. Untuk lebih jelasnya maka rancangan digambarkan sebagai berikut:

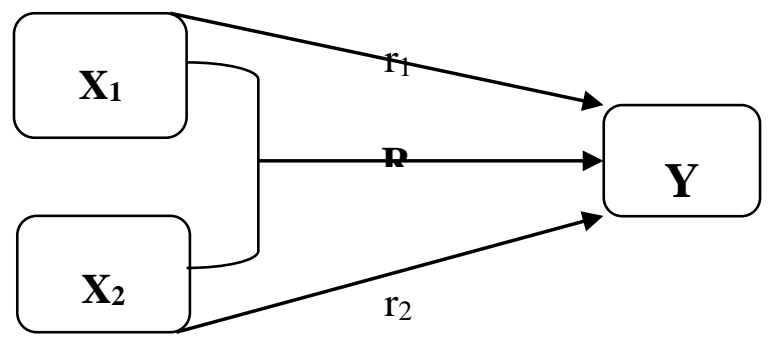

Gambar 01. Konstalasi Penelitian (Sugiyono,2017)

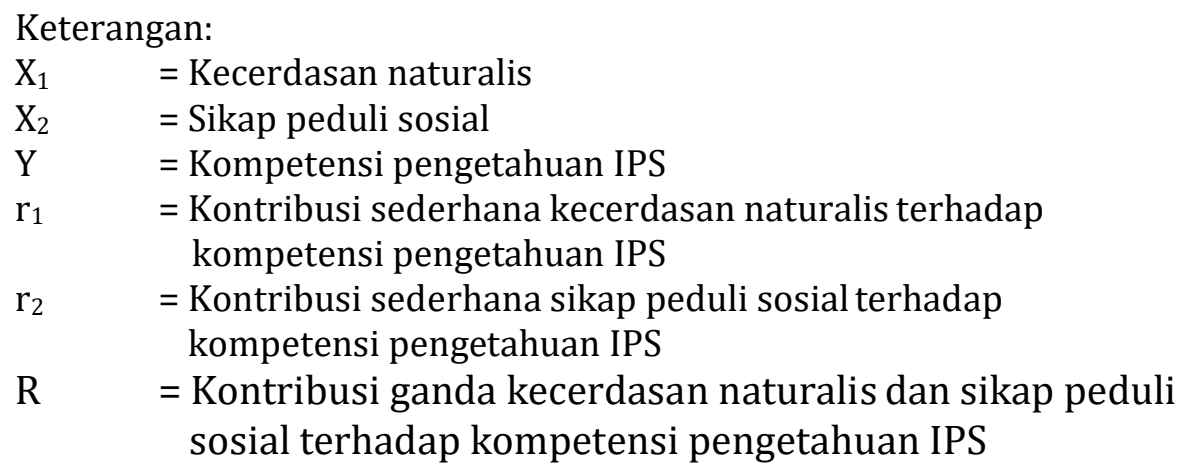

Ex post facto mulai dengan deskripsi situasi sekarang, yang diasumsikan sebagai akibat dari faktor-faktor sebelumnya telah ada dan memengaruhi peneliti berusaha meneliti kebelakang untuk menentukan faktor yang diasumsikan sebagai penyebab, yang mulai beroprasi pada masa yang lalu. 
Agar kita dapat menyimpulkan hubungan semacam sebab-akibat antar variabel tersebut, harus dapat dikumpulkan fakta (baik logika teori atau data empirik). Menurut Kerlinger (dalam Emzir 2015) expost facto adalah penyelidikan empiris yang sistematis dimana ilmuwan tidak mengendalikan variabell bebas secara langsung karena eksistensi dari variable terseut telah terjadi, atau karena variable tersebut pada dasarnya tidak dapat dimanipulasi. Jadi penelitian ex post facto adalah penyelidikan empiris sistematis yang tidak mengendalikan variabel bebas secara langsung karena perwujudan variabel tersebut telah terjadi dengan mengambil kelompok-kelompok yang berbeda dan peneliti berusaha menentukan perbedaan-perbedaan ini untuk menentukan faktor yang diasumsikan sebagai penyebab, yang mulai beroprasi pada masa yang lalu. Adapun variabel dalam penelitian ini terdiri dari variabel terikat dan variabel bebeas, Variabel terikat adalah aspek perilaku yang diamati dari organisme yang telah diberi stimulasi, yang menjadi variabel terikat dalam penelitian ini adalah kompetensi pengetahuan IPS.

Variabel bebas adalah variabel yang mempengaruhi atau yang menjadi sebab perubahannya atau timbulnya variabel dependen (terikat), yang menjadi variablel bebas dalam penelitian ini adalah kecerdasan naturalis dan sikap peduli sosial. Populasi adalah wilayah generalisasi yang terdiri atas objek atau subyek yang mempunyai kualitas dan karakteristik tertentu yang ditetapkan oleh peneliti untuk dipelajari dan kemudian ditarik kesimpulannya" (Sugiyono, 2013:80). Sedangkan menurut Agung (2014: 47) mengatakan populasi merupakan keseluruhan objek dalam suatu penelitian. Jadi berdasarkan penjelasan tersebut dapat dirangkum bahwa populasi adalah kumpulan dari orang yang memiliki kualitas dan karakteristik tertentu yang ingin diteliti oleh peneliti lalu dipelajari dan ditarik kesimpulan. Populasi dalam penelitian ini adalah semua siswa kelas IV SD Negeri Gugus III Mengwi tahun pelajaran 2018/2019 yang terdiri dari 7 sekolah. Jumlah populasi di Gugus III Kecamatan Mengwi sebanyak 264 orang.

Setelah mengetahui populasi langkah selanjutnya menentukan sampel penelitian sampel adalah sekelompok objek, orang, peristiwa, dan sebagainya yang merupakan representasi dari keseluruhan" (Setyosari, 2013:220). Selain itu Sugiyono (2013:81) menyatakan sampel adalah "bagian dari jumlah dan karakteristik yang dimiliki oleh populasi tersebut". Jadi dapat dirangkum bahwa sampel adalah bagian dari populasi berupa objek, orang, peristiwa dan sebagainya serta memiliki karakteristik populasi atau representasi dari keseluruhan. Penggunaan sampel bertujuan untuk menghemat waktu, tenaga, dan biaya dalam melakukan penelitian.

Teknik yang digunakan mengambil sampel dari populasi disebut teknik Proposional Random Sampling Menurut Sugiyono (2013:82) teknik sampling proporsional adalah "teknik proporsional sampel digunakan bila populasi memiliki anggota atau unsur yang tidak homogen dan berstrata secara proporsional". Selain itu Agung (2014:76) menyatakan sampel proporsional adalah "teknik sampel ini merupakan penyempurnaan dari teknik sampel berstrata dan sampel wilayah". Hal ini dilakukan untuk lebih menjamin representatifnya sampel jika ternyata jumlah subjek yang terdapat dalam tiap strata atau tiap wilayah tidak sama. Proporsional sampel merupakan jumlah sampel yang diambil dari strata yang sebanding, sesuai dengan proporsional ukurannya. Random adalah pengambilan data sampel dari populasi dilakukakn secara acak. Jadi tehnik proporsonal random sampling adalah tehnik pengambilan sampel secara acak dengan memperhatikan jumlah siswa dari masing-masing kelas. Dalam penentuan sampel dapat dilihat pada tabel Issac and Michel. Dalam tabel tersebut dijelaskan tentang besarnya sampel yang diambil dari populasi dengan tingkat kesalahan 1\%, 5\%, dan 10\%. Sesuai dengan tabel tersebut, jumlah populasi di Gugus III Kecamatan Mengwi sebanyak 264 orang, sedangkan populasi yang ada dalam tabel Issac and Michel yang mendekati jumlah populasi di gugus III Mengwi adalah 260 orang, jadi jumlah sampel yang diambil dengan tingkat kesalahan 5\% adalah 149 orang. Dalam suatu penelitian untuk memperoleh data informasi perlu adanya kegiatan pengumpulan data. Pengumpulan data dalam penelitian dapat dikumpulkan melalui metode non tes, metode non test dapat didefinisikan sebagai teknik kendala untuk memperoleh gambaran terutama mengenai karakteristik, sikap, atau kepribadian. Dengan teknik non test maka penilaian atau evaluasi belajar peserta didik dilakukan dengan tanpa menguji peserta didik, melainkan dilakukan dengan melakukan pengamatan secara sistematis (observation), melakukan wawancara (interview), menyebarkan angket (questionnaire), dan memeriksa atau meneliti dokumen-dokumen. 
Metode non tes merupakan cara memperoleh atau mengumpulkan data dengan mengirimkan suatu daftar pertanyaan atau pertanyaan-pertanyaan kepada responden atau subjek penelitian. Dengan instrument dalam bentuk angket untuk memperoleh data kacerdasan naturalis dan sikap peduli sosial, sedangkan data kompetensi pengetahuan IPS diperoleh dari pencatatan dokumen. Pengujian instrument pada penelitian ini yaitu terdiri dari uji validitas dan uji reliabilitas. Setelah dilakukannya uji instrument pada angket kecerdasan naturalis dan sikap peduli sosial di dapat 30 jumlah pernyataan yang valid pada kecerdasan naturalis dan 30 jumlah pernyataan yang valid pada sikap peduli sosial. Instrumen penelitian ini menggunakan skala likert sebagai skala pengukuran yaitu kecerdasan naturalis dan sikap peduli sosial. Skala likert digunakan untuk mengukur sikap, pendapat, dan persepsi seseorang atau sekelompok orang tentang fenomena sosial. Dengan skala likert maka variabel yang diukur dijabarkan menjadi indikator variabel. Jawaban setiap item instrumen yang menggunakan skala likert mempunyai gradasi dari sangat positif sampai sangat negatif, yang dapat berupa kata-kata sangat setuju, setuju, tidak setuju, sangat tidak setuju. Cara pemberian skornya adalah untuk statemen yang positif pilihan sangat setuju skornya 4, setuju skornya 3, tidak setuju skornya 2, dan sangat tidak setuju skornya 1. Sedangkan, untuk statemen yang negatif pilihan sangat setuju skornya 1 , setuju skornya 2 , tidak setuju skornya 3, dan sangat tidak setuju skornya 4.

\section{Tabel 1}

Cara Pemberian Skor

\begin{tabular}{lcc}
\hline \multicolumn{1}{c}{ Pernyataan } & \multicolumn{2}{c}{ Skor } \\
\cline { 2 - 3 } & Positif & Negatif \\
\hline Sangat setuju & 4 & 1 \\
\hline Setuju & 3 & 2 \\
\hline Tidak setuju & 2 & 3 \\
\hline Sangat tidak setuju & 1 & 4 \\
\hline
\end{tabular}

(Sugiyono, 2016: 135)

Sebelum dilakukannnya uji analisis perlu dilakukannya uji prasyarat analisis. Uji prasyarat analisis yang dilakukan terdiri dari uji normalitas, uji linieritas, uji multikolinieritas dan uji heteroskedastisitas. Setelah dilakukannya uji prasyarat dilanjutkan dengan uji hipotesis dengan uji analisis regresi linier sederhana dan uji analisis regresi linier ganda. Uji analisis linier sederhana digunakan untuk menguji hipotesis pertama dan kedua dengan persamaan regresi

$$
\hat{Y}=a+b X
$$

(Siregar, 2015:220)

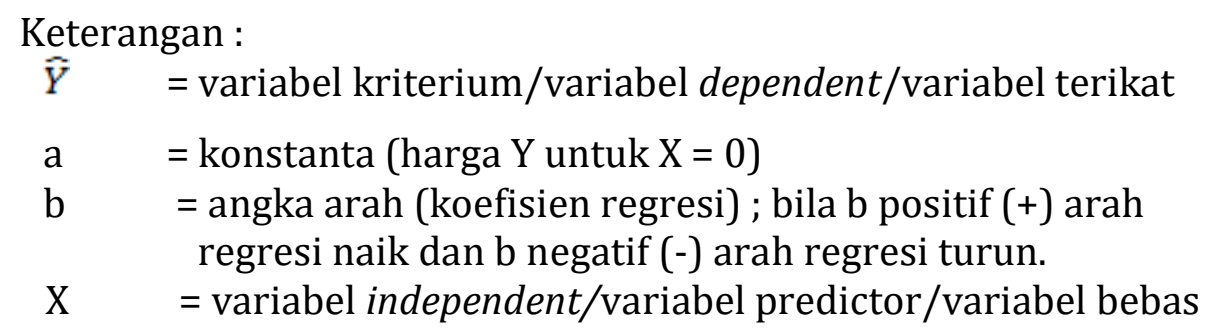

sedangkan uji analisis regresi linier ganda digunakan untuk menguji hipotesis ketiga dengan persamaan regresi.

$$
\hat{\mathrm{Y}}=\mathrm{a}+b_{1} X_{1}+b_{2} X_{2}
$$


Keterangan :

$\widehat{Y}$

a $\quad=$ konstanta regresi ganda (harga $\mathrm{Y}$ untuk $\mathrm{X}=0$ )

$\mathrm{b}_{1} \quad=$ angka arah (koefisien regresi $\mathrm{X}_{1}$ ) ; bila b positif $(+)$ arah regresi naik dan $b$ negatif $(-)$ arah regresi turun.

$\mathrm{b}_{2} \quad=$ angka arah (koefisien regresi $\left.\mathrm{X}_{2}\right)$; bila b positif $(+)$ arah regresi naik dan b negatif $(-)$ arah regresi turun.

$\mathrm{X}_{1} \quad=$ variabel independent /variabel bebas (kecerdasan naturalis)

$\mathrm{X}_{2} \quad=$ variabel independent /variabel bebas (sikap peduli sosial)

Pengujian hipotesis dilakukan untuk mengetahui tercapai atau tidaknya tujuan penelitian dalam penelitian ini Hipotesis yang diuji dalam penelitian ini adalah $\mathrm{H}_{\mathrm{o}}$ yang menyatakan bahwa

1)Tidak terdapat pengaruh yang signifikan kecerdasan naturalis terhadap kompetensi pengetahuan IPS pada siswa Kelas IV SD Gugus III Mengwi

2) Tidak terdapat pengaruh yang signifikan sikap peduli sosial terhadap kompetensi pengetahuan IPS pada siswa Kelas IV SD Gugus III Mengwi

3) Tidak terdapat pengaruh yang signifikan kecerdasan naturalis dan sikap peduli sosial terhadap kompetensi pengetahuan IPS pada siswa Kelas IV SD Gugus III Mengwi

\section{Hasil dan Pembahasan}

Pengujian hipotesis pertama dengan analisis regresi sederhana diperoleh persamaan regresi $\hat{Y}=$ $23,720+0,312 X_{1}$ signifikan dan linier. Persmaan regresi yang telah didapat berarti bahwa setiap kenaikan 1 kali satuan kecerdasan naturalis menyebabkan kenaikan 0,312 nilai kompetensi pengetahuan IPS pada konstanta 23,720 , sehingga $\mathrm{H}_{0}$ yang menyatakan tidak terdapat pengeruh yang signifikan kecerdasan naturalis terhadap kompetensi pengetahuan IPS siswa Kelas IV SD Gugus III Mengwi ditolak dan $\mathrm{H}_{\mathrm{a}}$ diterima. Hasil analisis data diperoleh koefisien determinasi $\mathrm{R}^{2}=0,026$ dan kontribusinya sebesar 2,6\%. Hal ini berarti terdapat pengaruh yang signifikan kecerdasan naturalis terhadap kompetensi pengetahuan IPS siswa Kelas IV SD Gugus III Mengwi dan kontribusinya sebesar $2,6 \%$.

Pengujian hipotesis kedua dengan analisis regresi sederhana diperoleh persamaan regresi $\hat{Y}=$ $26,199+0,285 X_{2}$ signifikan dan linier. Persamaan regresi yang telah didapat berarti bahwa setiap kenaikan 1 kali satuan sikap peduli sosial menyebabkan kenaikan 0,285 nilai kompetensi pengetahuan IPS pada konstanta 26,199 , sehingga $\mathrm{H}_{0}$ yang menyatakan tidak terdapat pengeruh yang signifikan kecerdasan naturalis terhadap kompetensi pengetahuan IPS siswa Kelas IV SD Gugus III Mengwi ditolak dan $\mathrm{H}_{\mathrm{a}}$ diterima. Hasil analisis data diperoleh koefisien determinasi $\mathrm{R}^{2}=0,028$ dan kontribusinya sebesar 2,8\%. Hal ini berarti terdapat pengaruh yang signifikan sikap peduli sosial terhadap kompetensi pengetahuan IPS siswa Kelas IV SD Gugus III Mengwi dan kontribusinya sebesar $2,8 \%$.

Pengujian hipotesis ketiga dengan analisis regresi ganda diperoleh persamaan regresi $\hat{Y}=3,286$ $+0,275 \mathrm{X}_{1}+0,254 \mathrm{X}_{2}$ signifikan dan linier. Persmaan regresi yang telah didapat berarti bahwa setiap kenaikan 1 kali satuan kecerdasan naturalis dan sikap peduli sosial menyebabkan kenaikan 0,275 dan 0,254 nilai kompetensi pengetahuan IPS pada konstanta 3,386, sehingga $\mathrm{H}_{0}$ yang menyatakan tidak terdapat pengeruh yang signifikan kecerdasan naturalis dan sikap peduli sosial terhadap kompetensi pengetahuan IPS siswa Kelas IV SD Gugus III Mengwi ditolak dan $\mathrm{H}_{\mathrm{a}}$ diterima. Hasil analisis data diperoleh koefisien determinasi $\mathrm{R}^{2}=0,048$ dan kontribusinya sebesar 4,8\%. Hal ini berarti terdapat pengaruh yang signifikan kecerdasan naturalis dan sikap peduli sosial terhadap kompetensi pengetahuan IPS siswa Kelas IV SD Gugus III Mengwi dan kontribusinya sebesar 4,8\%. Hal ini memperlihatkan bahwa terdapat faktor lain yang mempengaruhi kompetensi pengetahuan IPS sebesar 95,2\%, baik dari faktor internal maupun faktor eksternal, faktor internal yaitu, intelegensi, 
minat, bakat sikap tanggung jawab, rasa ingin tahu, faktor eksternal lingkungan belajar, hubungan sosial.

\section{Simpulan}

Berdasarkan analisi yang telah dilaksanakan maka dapat disimpulkan bahwa: (1) Pengujian hipotesis pertama menggunakan analisis regresi linier sederhana dengan persamaan garis regresi $\hat{Y}=23,720+0,312 X_{1}$. Signifikan dan linier. persamaan regresi yang sudah didapat serta uji prasyarat yang sudah memenuhi kriteria yaitu bahwa setiap kenaikan 1 skor kecerdasan naturalis menyebabkan kenaikan 0,312 nilai kompetensi pengetahuan IPS pada konstanta 23,720, sehingga $\mathrm{H}_{0}$ yang menyatakan tidak terdapat pengaruh yang signifikan kecerdasan naturalis terhadap kompetensi pengetahuan IPS siswa kelas IV SD Gugus III Mengwi ditolak dan $\mathrm{H}_{a}$ yang menyatakan terdapat pengaruh yang signifikan antara kecerdasan naturalis terhadap kompetensi pengetahuan IPS diterima. Hasil analisi data diperoleh adalah $\mathrm{R}^{2}=0,026$ atau kontribusinya sebesar 2,6\% hal ini berarti terdapat hubungan yang signifikan antara kecerdasan naturalis terhadap kompetensi pengetahuan IPS sebesar 2,6\%; (2) Pengujian hipotesis kedua menggunakan analisis regresi linier sederhana dengan persamaan garis regresi $\hat{Y}=26,199+0,285 X_{2}$. Signifikan dan linier. persamaan regresi yang sudah didapat serta uji prasyarat yang sudah memenuhi kriteria yaitu bahwa setiap kenaikan 1 skor sikap peduli sosial menyebabkan kenaikan 0,285 nilai kompetensi pengetahuan IPS pada konstanta 26,199, sehingga $\mathrm{H}_{0}$ yang menyatakan tidak terdapat pengaruh yang signifikan sikap peduli sosial terhadap kompetensi pengetahuan IPS siswa kelas IV SD Gugus III Mengwi ditolak dan $\mathrm{H}_{a}$ yang menyatakan terdapat pengaruh yang signifikan antara sikap peduli sosial terhadap kompetensi pengetahuan IPS diterima. Hasil analisi data diperoleh adalah $\mathrm{R}^{2}=0,028$ atau kontribusinya sebesar $2,8 \%$ hal ini berarti terdapat hubungan yang signifikan antara sikap peduli sosial terhadap kompetensi pengetahuan IPS sebesar 2,8\%; (3) Pengujian hipotesis ketiga menggunakan analisis regresi linier ganda dengan persamaan garis regresi $\hat{Y}=3,286+0,275 X_{1}+0,254 X_{2}$. Signifikan dan linier. Persamaan regresi yang sudah didapat serta uji prasyarat yang sudah memenuhi kriteria yaitu bahwa setiap kenaikan 1 skor kecerdasan naturalis dan sikap peduli sosial menyebabkan kenaikan 0,275 dan 0,254 nilai kompetensi pengetahuan IPS pada konstanta 3,286, sehingga $\mathrm{H}_{0}$ yang menyatakan tidak terdapat pengaruh yang signifikan kecerdasan naturalis dan sikap peduli sosial terhadap kompetensi pengetahuan IPS siswa kelas IV SD Gugus III Mengwi ditolak dan $\mathrm{H}_{\mathrm{a}}$ yang menyatakan terdapat pengaruh yang signifikan antara kecerdasan naturalis dan sikap peduli sosial terhadap kompetensi pengetahuan IPS diterima. Hasil analisi data diperoleh adalah $\mathrm{R}^{2}=0,048$ atau kontribusinya sebesar $4,8 \%$ hal ini berarti terdapat hubungan yang signifikan antara kecerdasan naturalis dan sikap peduli sosial terhadap kompetensi pengetahuan IPS sebesar 4,8\%;

Sebagai tindak lanjut dari hasil penelitian, maka penelitian ini disarankan kepada (1) Siswa untuk mampu dalam menumbuhkan rasa sikap peduli sosial, agar siswa mempunyai rasa peduli yang tinggi dan dapat berinteraksi dengan orang lain di sekolah maupun masyarakat di sekitar; (3) Guru diharapkan dapat menjadi acuan untuk meningkatkan kecerdasan naturalis dan sikap peduli sosial siswa agar tercapai kompetensi pengetahuan IPS yang baik; (4) Penelitian ini dapat menjadi masukan berharga bagi Kepala Sekolah selaku pengambil kebijakan yang nantinya kebijakan tersebut dapat memperlancar proses kegiatan pembelajaran; (5) Penelitian ini dapat dijadikan sebagai salah satu referensi bagi para peneliti bidang pendidikan karakter sebagai bahan untuk mendalami objek penelitian yang sejenis; 


\section{Daftar Rujukan}

Agung, A.A Gede. 2014. Metodelogi Penelitian Pendidikan. Singaraja: Universitas Pendidikan Ganesha.

Ahmadi, H.Abu.2009.Psikologi Sosial. Jakarta: Rineka Cipta.

Amstrong,Tomas. 2013. Kecerdasan Multipel di dalam Kelas. Jakarta: Indeks.

Anna,Choerul. 2016. Hubungan Antara Kecerdasan Naturalis Dengan Sikap Peduli Lingkungan Siswa Kelas III Sekolah Dasar Negeri Se-Kecamatan Gondokusuman Yogyakarta. Skripsi (Tidak Diterbitkan). Jurursan PGSD. FIP Universitas Negeri Yogyakarta.

Arikunto, Suharsimi. 2013. Dasar-Dasar Evaluasi Pendidikan. Jakarta: Bumi Aksara.

Budiningsih, Belajar dan Pembelajaran, Jakarta: Rineka Cipta, 2005.

Dantes, Nyoman. 2012. Metodologi Penelitian Untuk Ilmu-Ilmu Sosial dan Humaniora. Singaraja: Universitas Pendidikan Ganesha.

Darmadi, Hamid. 2014 Metode Penelitian Pendidikan dan Sosial. Bandung: Alfabeta.

Emzir. 2008. Metodologi Penelitian Pendidikan Kuantitatif dan Kualitatif. Jakarta: PT Rajagrafindo Persada.

Gardner,Howard. 2013. Multiple Intelegences. Jakarta: Daras Books.

Gunawan, Heri. 2012. Pendidikan Karakter Konsep dan Implementasi. Bandung: Alfabeta.

Gunawan, Rudy. 2013. Pendidikan IPS Filosifi, Konsep, dan Aplikasi. Bandung: Alfabeta.

Hamalik, Oemar. 2001. Proses Belajar Mengajar. Bandung: Bumi Aksara.

Hutagalung,Hj.Inge. 2007. Pengembangan Kepribadian Tujuan Praktis Menuju Pribadi Positif. Indonesia : PT Macana Jaya Cemerlang.

Ismail,Affandi.2018.Pengembangan Instrumen Naturalis Anak Usia Dini di Kabupaten Luwu TimurProvinsi Sulawesi Selatan. Skripsi (Tidak Diterbitkan). Universitas Negeri Jakarta.

Komalasari, Kokom. 2010. Pembelajaran Kontekstual: Konsep dan Aplikasi. Refika Aditama. Bandung.

Komalasari, Komkom dan Didin, Saripudin. 2017. Pendidikan Karakter. Bandung: Refika Aditama.

Kosasih, E. 2014. Strategi Belajar dan Pembelajaran Implementasi Kurikulum 2013. Bandung: yrama Widya.

Kunandar. 2014. Penilaian Autentik Penilaian Hasil Belajar Peserta Didik

Berdasarkan Kurikulum 2013 Suatu Pendekatan Praktis Disertai

dengan Contoh. Depok: Rajagrafindo Persada.

Lasmayan, Wayan. 2016. Pendidikan IPS. Singaraja : Mediakom Indonesia Press Bali.

Maksum.Ali. 2016 Sosiologi Pendidikan. Jatim: Madani Wisma Kalimetro

Mandari,Kadek. 2018. Korelasi Antara Sikap Peduli Sosial Dengan Interaksi Sosial Siswa Kelas IV SD Gugus VII Mengwi Tahun Pelajaran 2017/2018. Skripsi (Tidak Diterbitkan) Jurursan PGSD. FIP Undiksha.

Pratama,Wisnu. 2017. Analisis Partisipasi Siswa dalam Menjaga Kesehatan Lingkungan Ditinjau Melalui Kecerdasan Naturalis. Skripsi (Tidak Diterbitkan). Jurusan Biologi. FKIP UNIMED.

Setyosari, Punaji. 2012. Metode penelitian Pendidikan \& Pengembangan. Jakarta: Prenamedia Group.

Sholeh, Khabib, dkk. 2016. Kecerdasan Majemuk Berorientasi pada Partisipasi. Yogyakarta: Pustaka Belajar. 
Simanjuntak, Hanna. 2017. Hubungan Antara Kecerdasan Naturalis Dengan Sikap Peduli Lingkungan Siswa Smpn 7 Bandar Lampung. Skripsi (Tidak Diterbitkan). FKIP Universitas Lampung.

Slameto. 2010. Belajar dan Faktor-Faktor yang Mempengaruhi. Jakarta: Rineka Cipta.

Soekanto, Soerjono. (2012). Sosiologi Suatu Pengantar. Jakarta : PT. Rajagrafindo Persada.

Sudiana, Nyoman. 2013. Interaksi Belajar Mengajar Bahasa dan Sastra Indonesia. Surabaya: Media Ilmu.

Sugiyono. 2013. Metode Penelitian Pendidikan Pendekatan Kuantitatif, Kualikatif dan R\&D. Bandung: Alfabeta.

Sugiyono. 2016. Metode Penelitian Pendidikan. Bandung: Alfabeta.

Sunarto, B.Agung Hartono. 2002. Perkembangan Peserta Didik. Jakarta: PT Rineka Cipta.

Susanto, Ahmad. 2014. Teori Belajar \& Pembelajaran di Sekolah Dasar. Jakarta: PT Fajar Interpratama Mandiri

Uno, Hamzah. 2006. Orientasi Baru dalam Psikologi Pembelajaran. Jakarta: Bumi Aksara.

Yusuf, A.Muri. 2017. Asesment dan Evaluasi. Jakarta : PT Fajar Interpratama Mandiri.

Yusuf, Syamsu, dan Nami M. Sugandi. 2013. Perkembangan Peserta Didik. Jakarta: Rajawali Pers

Zubaedi. 2011. Desain Pendidikan Karakter, Konsepsi dan Aplikasinya dalam Lembaga Pendidikan. Jakarta : Kencana Prenada. 